\title{
The Role of the Board Of Commissioners and The Sharia Supervisory Board Towards The Financial Performance of Islamic Rural Bank
}

\author{
Ridwansyah $^{1}$, Mahatma Kufepaksi ${ }^{2}$, Rindu Rika Gamayuni ${ }^{3}$, Ayi Ahadiat ${ }^{4}$, Nur Wahyu \\ Ningsih ${ }^{5}$ \\ \{ridwansyah@radenintan.ac.id', mahapaksi@yahoo.com², rindu.gamayuni@yahoo.com³, \\ ayiahadiat@unila.ac.id ${ }^{4}$, nurwahyu@radenintan.ac.id ${ }^{5}$ ?
}

\begin{abstract}
Islamic State University of Raden Intan, Jln. Letkol Endro Suratmin No. 1, Bandar Lampung, 35131, Lampung, Indonesia ${ }^{1,5}$, Lampung University, Jln. Soemantri Brodjonegoro No. 1,Bandar Lampung, 35141, Lampung, Indonesia ${ }^{2,3,4}$
\end{abstract}

\begin{abstract}
This research is a contextual research. The purpose of this study was to examine the effect of the role of the board of commissioners and the Sharia Supervisory Board on the financial performance of sharia banks, in this case the Islamic Rural Bank. The financial performance are CAR, ROA, ROE. Agency, stakeholder and signaling theory can explain the relationship of these variables. The analysis uses path analysis, the significance of the $\mathrm{F}$ model test and the $\mathrm{T}$ independent variable test. The results of this research will be beneficial for Islamic banking in terms of banking policy which are it is expected to be used as a consideration by the Islamic People's Financing Bank in Indonesia and related regulators, in this case the FSA and Bank Indonesia, as a reference in the formulation of rules regarding Islamic Rural Bank risk management, especially regarding the board of commissioners and the sharia supervisory board
\end{abstract}

Keywords: Board of Commissioners, Sharia Supervisory Board, CAR, ROA, ROE

\section{Introduction}

Sharia banks in Indonesia were born for the first time in 1992 with the start of the operation of Bank Muamalat Indonesia and Islamic banks continue to experience growth. Based on statistical data released by the Financial Services Authority, at the end of 2017 there were 13 Sharia Commercial Banks with 21 Sharia Business Units and 167 Islamic Rural Banks in Indonesia. In carrying out its operational activities, banks based on sharia principles do not use the interest system in determining the compensation for funds used or deposited by a party. The development of Islamic banking became more apparent after legalization of Law Number 21 of 2008 concerning sharia banking in carrying out business activities based on sharia principles. With the enactment of that law, the sharia banking industry is expected to develop even better, not only regarding the products and services that are transacted, but also the value of the transactions. One of the advantages given by Law Number 10/1998 is that this Act still accommodates a dual banking system. Current system: Sharia Business Unit (UUS) which is a parent of conventional commercial banks (BUK) is still valid.

According to Law Number 40 of 2007 concerning Limited Liability Companies Article 109, companies that carry out business activities based on sharia principles must have a SSB. Sharia Supervisory Board has an important and strategic role in the application of sharia 
principles in sharia banking, both in Islamic Commercial Banks (BUS) and in Islamic Rural Banks. The existence of Board of Commissioners and SSB in Islamic Rural Banks is regulated separately through the Financial Services Authority Regulation number 3 / 03.POJK / 2016 concerning Islamic Rural Banks. Based on the two laws, the position of Board of Commissioners and Sharia Supervisory Board has clearly determined the development of sharia banks and sharia principle companies in the present and the future. Yet the role of Sharia Supervisory Board is not yet optimal in carrying out sharia supervision of sharia banking operations. So that it results in violations of sharia compliance, then the image and credibility of sharia banks in the eyes of the public can be negative, this can reduce public trust in sharia banks.

Many people say that the length of the process of repairing the crisis problem that occurred in Indonesia is due to the weak concept of supervision from the board of commissioners and the SSB applied in companies in Indonesia. Since then, both the government and investors have begun to pay significant attention to the practice and implementation of the roles of the Board of Commissioners and the SSB. An increase in the number of sharia banks and sharia banking offices operating in Indonesia has a positive impact on the development of the sharia banking industry. Yet the role of the SSB is not yet optimal in carrying out sharia oversight of sharia banking operations. So that it results in violations of sharia compliance, then the image and credibility of sharia banks in the eyes of the public can be negative, this can reduce public trust in sharia banks.

The risk of sharia banking focuses on financial problems since the banking business is a business engaged in financial services. Banking risk is the risk experienced by the banking business sector as a form of various decisions made in various fields such as lending decisions, issuance of credit cards, foreign exchange, collections and various other forms of financial decisions which have caused the greatest losses in the form of financial. The roles, duties and responsibilities carried out by the Sharia Supervisory Board are solely carried out to ensure sharia bank compliance with sharia principles, which are the main objectives of sharia governance. According to Bank Negara Malaysia the aim of sharia governance is to ensure all operations and business activities of sharia banks are in line with sharia principles, provide comprehensive guidelines for the board of commissioners and the SSB, and underline the functions related to sharia review, sharia audit, sharia risk management and sharia research. In addition to the problems mentioned above, problems that often occur in Islamic Rural Bank include cost of funds, funding, high risk financing, unclear business models and good corporate governance ${ }^{1}$.

Islamic Rural Bank performance can be assessed using the financial ratio analysis approach. The soundness of a bank is regulated by Bank Indonesia in a Circular Letter of Bank Indonesia Number 9/29 / DPBS dated December 7, 2007, concerning the soundness rating system of rural banks based on sharia principles, banks are required to conduct a bank soundness assessment. This study uses several ratios of financial performance of banks, namely CAR, ROA and ROE.

Table 1. Financial Performance Islamic Rural Banks at Indonesia per 2015-2019

\footnotetext{
${ }^{1}$ Bank Negara Malaysia. Bank Negara Malaysia: Shariah Resolution in Islamic Finance. Bank Negara Malaysia, 2010.
} 


\begin{tabular}{cccccc}
\hline Ratio & $\mathbf{2 0 1 5}$ & $\mathbf{2 0 1 6}$ & $\mathbf{2 0 1 7}$ & $\mathbf{2 0 1 8}$ & $\mathbf{2 0 1 9}$ \\
\hline CAR & $21,47 \%$ & $21,73 \%$ & $20,81 \%$ & $19,33 \%$ & $17,99 \%$ \\
ROA & $2,20 \%$ & $2,27 \%$ & $2,55 \%$ & $1,87 \%$ & $2,61 \%$ \\
ROE & $14,66 \%$ & $16,18 \%$ & $19,40 \%$ & $12,86 \%$ & $27,30 \%$ \\
\hline
\end{tabular}

Based on table 1 above, it can be seen that there was a fluctuation in the financial performance of Islamic Rural Bank for the 2015-2019 period.

\section{Literature Review}

\subsection{Agency Theory}

Agency theory reveals that each individual is focused by his own interests, giving rise to a conflict between the principal and the agent. The principal contracts the agent to manage the resources in the company and is obliged to provide rewards to the agent while the agent is obliged to manage the resources owned by the company and is responsible for the tasks assigned to $\mathrm{it}^{2}$. This theory is often used in research on the existence of the committee because it consist of internal and external supervision. Generally, the committee is predicted to exist when the agency cost situation tends to be high, for example high leverage, and a sizeable bank.

\subsection{Stakeholders Theory}

While the definition of stakeholders according to freeman is any group or individual that can influence or be influenced by the achievement of organizational goals ${ }^{3}$. Signal theory suggests about how a company should be a good institution (in this study Islamic Rural Bank) gives a signal to users of financial statements (external parties). The purpose of the bank to provide information is to minimize information asymmetry between the bank and exterbal parties. Lack of information for outsiders will provide low prices for banks. Banks can increase the value of banking by reducing information asymmetry by giving signals to outsiders, in the form of information ${ }^{4}$.

\subsection{The Role of the Board of Commissioners towards Financial Performance}

Research Rahman and Jusoh indicates that a qualified board of directors and sharia supervisory board is needed by the organization to ensure the direct functioning of the board is good to fulfill the best performance ${ }^{5}$. Meiryani's observed that institutional ownership, the board of commissioners, the audit committee, earnings affected the financial performance of banks on the IDX ${ }^{6}$. The independent board and the board of commissioners influence the

${ }^{2}$ M. C. Jensen, W. H. Meckling. Theory of The Firm: Managerial Behavior, Agency Costs and Ownership Structure, J. Financ. Econ. 1975. doi: 10.1016/0304-405X(76)90026-X.

${ }^{3}$ E. R. Freeman, W. M. Evan. A Stakeholder Theory of The Modern Corporation: Kantian Capitalism. Ethical Theory and Business; 1979.

${ }^{4}$ M. Spence. Job Market Signaling. Q. J. Econ. 1973. doi: 10.2307/1882010.

${ }^{5}$ N. A. Rahman, M. A. Jusoh. A Review of Board of Director, Shariah Supervisory Board and Zakat Distribution Performance in Malaysia. Int. J. Acad. Res. Bus. Soc. Sci. 2018. doi: 10.6007/ijarbss/v8i2/3985.

6 Meiryani. Mechanism of Good Corporate Governance, Earnings Management on Financial Performance in Banks Listed in Indonesia Stock Exchange Using Path Analysis. Aust. J. Basic Appl. 
financial performance of companies listed on the Nairobi Stock Exchange ${ }^{7}$. Board of commissioners, directors, independent commissioners significantly influence financial performance ${ }^{8}$. Based on the theory and previous research, the formulation of the first hypothesis is shown by the role of the board of commissioners influencing financial performance.

H1: There is a positive influence from Board of Commissioners to Financial Performance

\subsection{The Role of Sharia Supervisory Board towards Financial Performance}

Research by Van Ness and Kang found that duality, job expertise, board size, and board tenure have a significant effect on a company's financial performance 9 . Research Sukmono and Yadiati ${ }^{10}$ indicates that there is a significant positive effect on commissioners through the quality of financial reporting. Higher independent directors have higher ROE levels, but the results of investigations of effects on $\mathrm{ROA}^{11}$. Sharia organizations, namely sharia supervisory boards and disclosure $\&$ transparency reports are influenced by bank profitability, suggesting that the higher trust of sharia banks with members of the Sharia committee encourages them to be more transparent about bank performance ${ }^{12}$. Based on the theory and previous research, the formulation of the first hypothesis is shown by the role of the sharia supervisory board influencing financial performance. ROA is the company's capital ability to generate profits. In sharia banking a good ROA percentage is above $1.45 \%$. CAR is the ratio or ratio between bank capital and risk weighted assets (ATMR) with a CAR percentage above $11 \%$ categorized as good for a bank. Whereas ROE is measuring the company's ability to generate profits throught share capital with a criterion above $23 \%$, so it is said to be very good for banks.

H2: There is a positive influence from Sharia Supervisory Board to Financial Performance

\section{Research Method}

This research is a quantitative descriptive study that focuses on the analysis of the influence between the role of the board of commissioners and the SSB on the financial performance of the Islamic Rural Bank. This research relies on a positivistic paradigm as well as a quantitative approach ${ }^{13}$. The sample of this study were 160 Islamic Rural Bank at Indonesian. Companies selected sample of the population of Islamic Rural Bank at Indonesian

Sci. 2015; Vol. 9, No. 23: 573-584.

7 V. O. Ongore, P. O. K'Obonyo, M. Ogutu, E. M. Bosire. Board Composition and Financial Performance: Empirical Analysis of Companies Listed at the Nairobi Securities Exchange. Int. J. Econ. Financ. Issues. 2015.

${ }^{8}$ R. Gamayuni. The Effect of Intangible Asset Financial Performance and Financial Policies on the Firm Value. Int. J. Sci. Technol. Res. 2015

${ }^{9}$ R. K. Van Ness, P. Miesing, J. Kang. Board of Director Composition and Financial Performance in Sarbanes-Oxley World. Acad. Bus. Econ. J. 2010.

${ }^{10} \mathrm{~S}$. Sukmono, W. Yadiati. Effect of Board of Commissioners and Audit Committee on the Firm Value With Mediating Effect Financial Reporting Quality. Res. J. Financ. Accounting Online. 2016.

${ }^{11}$ K. Veklenko. The Impact of Board Composition on The Firm's Performance in Continental Europe, IBA Bachelor Thesis Conference; 2016.

${ }^{12}$ R. Masruki, M. M. Hanefah, N. A. Wahab. Shariah Supervisory Board (SSB) and Performance of Islamic Banks in Malaysia. 2018.

${ }^{13}$ M. H. A. Ong, F. Puteh. Quantitative Data Analysis : Choosing Between SPSS, PLS and AMOS in Social Science Research. Int. Interdiscip. J. Sci. Res. 2017; Vol. 3, No. 1: 14-25. 
and based on the availability of data to calculate the variables described previously. The study period was from 2015 to 2019. Information in this study was sourced from research journals and textbooks both online and in print. The analysis uses path analysis, the significance of the $\mathrm{F}$ model test and the $\mathrm{T}$ independent variable test.

\section{Results and Analysis}

\subsection{Result}

The results of this research will be beneficial for Islamic banking in terms of banking policy which are it is expected to be used as a consideration by the Islamic People's Financing Bank in Indonesia and related regulators, in this case the FSA and Bank Indonesia, as a reference in the formulation of rules regarding Islamic Rural Bank risk management, especially regarding the board of commissioners and the sharia supervisory board. With this research, it is expected that the Indonesian Islamic Rural Bank can form a board of commissioners and SSB so as to minimize credit risk and improve the company's financial performance.

\subsection{Analysis}

Optimizing the role of the board of commissioners and SSB can be taken into consideration by the Sharia People's Financing Bank in Indonesia and related regulators, in this case the Financial Services Authority and Bank Indonesia as a reference in the formulation of rules regarding BPRS risk management, especially regarding the Board of Commissioners and the SSB . With this research, it is expected that the Indonesian Islamic Rural Bank can form a Board of Commissioners and SSB so as to improve financial performance through CAR, ROA and ROE. The findings are also expected to provide literature on the influence of the role of the board of commissioners, and the existence of the SSB on financial performance at the Islamic Rural Bank in Indonesia.

CAR is the ratio or ratio between bank capital and risk-weighted assets (ATMR), this will affect a bank's bad credit. If CAR decreases, then bad credit will increase resulting in declining company capital and will reduce annual profits. While ROA and ROE, the greater the percentage of ROA, the better the asset management of the company's profits and capital. With the role of the Board of Commissioners and the SSB the company's financial performance will be well controlled and will realize the company's business plan. The role of the Board of Commissioners as the party that approves and evaluates the company's business plans will make the company's management better in carrying out the company's operations. In addition, the role of the SSB as the executor in overseeing the DSN Fatwa in company operations.

The role of the board of commissioners in overseeing the implementation of Good Corporate Governance in each bank operational activity, ensuring directors follow up on audit findings or recommendations of Bank Indonesia, internal / external auditors or DPS, and the role of the board of commissioners forming a risk monitoring, remuneration and nomination and audit committee are efforts that can improve financial performance and risk management. The role of SSB is to supervise ad ensure the compliance of sharia banks with sharia principles in bank operations and products with the aim of improving the company's financial performance. This research will strengthen the theory and previous research which states that 
the importance of the aspect of supervision (monitoring) for the realization of good corporate governance. When viewed from an agency perspective, there are internal and external supervision. Lack of information for outsiders will provide low prices for banks. Banks can increase the value of banking by reducing information asymmetry by giving signals to outsiders, in the form of information. One of the good signals to produce good quality is to form a solid committee to provide better information than other banks.

\section{Conclusion}

This research can then be developed better by using analysis path to observe the influence of the role of the board of commissioners and the SSB on financial performance. The role of the sharia board of commissioners and SSB on the financial performance of the Islamic Rural Bank is a renewable research in the field of sharia banking, by maximizing the role of the sharia board of commissioners and supervisory board to improve the company's financial performance and maximize company profits. Thus, the results of this study will provide new evidence about the influence of the board of commissioners and SSB on financial performance.

\section{References}

[1] Bank Negara Malaysia. Bank Negara Malaysia: Shariah Resolution in Islamic Finance. Bank Negara Malaysia, 2010.

[2] M. C. Jensen, W. H. Meckling. Theory of The Firm: Managerial Behavior, Agency Costs and Ownership Structure, J. Financ. Econ. 1975. doi: 10.1016/0304-405X(76)90026-X.

[3] E. R. Freeman, W. M. Evan. A Stakeholder Theory of The Modern Corporation: Kantian Capitalism. Ethical Theory and Business; 1979.

[4] M. Spence. Job Market Signaling. Q. J. Econ. 1973. doi: 10.2307/1882010.

[5] N. A. Rahman, M. A. Jusoh. A Review of Board of Director, Shariah Supervisory Board and Zakat Distribution Performance in Malaysia. Int. J. Acad. Res. Bus. Soc. Sci. 2018. doi: 10.6007/ijarbss/v8-i2/3985

[6] Meiryani. Mechanism of Good Corporate Governance, Earnings Management on Financial Performance in Banks Listed in Indonesia Stock Exchange Using Path Analysis. Aust. J. Basic Appl. Sci. 2015; Vol. 9, No. 23: 573-584.

[7] V. O. Ongore, P. O. K’Obonyo, M. Ogutu, E. M. Bosire. Board Composition and Financial Performance: Empirical Analysis of Companies Listed at the Nairobi Securities Exchange. Int. J. Econ. Financ. Issues. 2015.

[8] R. Gamayuni. The Effect of Intangible Asset Financial Performance and Financial Policies on the Firm Value. Int. J. Sci. Technol. Res. 2015.

[9] R. K. Van Ness, P. Miesing, J. Kang. Board of Director Composition and Financial Performance in a Sarbanes-Oxley World. Acad. Bus. Econ. J. 2010.

[10] S. Sukmono, W. Yadiati. Effect of Board of Commissioners and Audit Committee on the Firm Value With Mediating Effect Financial Reporting Quality. Res. J. Financ. Accounting Online. 2016.

[11] K. Veklenko. The Impact of Board Composition on The Firm's Performance in Continental Europe, IBA Bachelor Thesis Conference; 2016.

[12] R. Masruki, M. M. Hanefah, N. A. Wahab. Shariah Supervisory Board (SSB) and Performance of Islamic Banks in Malaysia. 2018. 
[13] M. H. A. Ong, F. Puteh. Quantitative Data Analysis : Choosing Between SPSS, PLS and AMOS in Social Science Research. Int. Interdiscip. J. Sci. Res. 2017; Vol. 3, No. 1: 14-25. 